\title{
Waste management in major events and the relevance of environmental certification
}

\author{
L. Alves ${ }^{1,2}$, L. Freire ${ }^{3}$ \& E. Vazquez ${ }^{3}$ \\ ${ }^{1}$ Department of Civil Engineering, CEFET-RJ, Brazil \\ ${ }^{2}$ Federal University of Rio de Janeiro, COPPE/UFRJ, Brazil \\ ${ }^{3}$ Department of Civil Construction, Urban Engineering Program, \\ Federal University of Rio de Janeiro, UFRJ, Brazil
}

\begin{abstract}
The generation of solid waste is a major environmental problem faced by most urban centers in the world. The management, correct disposal and reuse, in the most appropriate and planned manner are daily challenges. Major events produce a huge amount of waste in a short time. The Rock in Rio event, originally Brazilian, had some editions in Europe and returned to Rio de Janeiro in 2011. This exchange has improved the event: it became environmentally committed, by adopting the label $100 \mathrm{R}$. The event is publicly committed to properly allocate as much of its waste as possible, and to contribute to social inclusion through a collectors' cooperative. This article aims to evaluate the tools used and the efficiency of the methodology adopted in the Rock in Rio event, seeking to define the most appropriate way to manage waste on events without affecting the dynamics of cities and, in addition, promote social inclusion and valuation of waste.
\end{abstract}

Keywords: solid waste, events, management, environmental certification.

\section{Introduction}

\subsection{Background and pertinent Brazilian legislation}

The rising population, along with rapid urbanization and industrialization, directly affects the amount of urban solid waste generated (Minghua et al. [1]). A common Brazilian accounts for approximately $378 \mathrm{~kg}$ of waste per year, according to the Brazilian Association of Public Cleaning Companies and Special Residues 
(ABRELPE $[1,2])$. The generation of solid waste is an important byproduct of socio-economic activities. The definition of solid waste varies among countries, generally including waste generated from industrial sector, commercial, domestic, institutional and municipal services (Srivastava et al. [3]).

In Brazil, laws aimed at environmental conservation began to be voted on 1981, with the creation of the National Environmental Policy law (Eigenheer [4]). The National Environmental Council (CONAMA), affiliated to the Brazilian Environmental and Natural Renewable Resources Institute (IBAMA), is also responsible for a number of resolutions that aimed to regulate the issue of solid waste.

Although the Brazilian environmental legislation is recognized as one of the most complete in the world since its creation, it is accompanied by a lack of supervision that affects the way it is met. Municipalities, usually responsible for managing urban solid waste in developing countries, are facing a challenge in providing an effective and dynamic system to the society. They usually fail to attain due to a lack of appropriate data collection system, lack of technical expertise and insufficient financial resources (Guerrero et al. [5]).

Environmental certifications are an alternative to the lack of commitment of the institutions regarding on solid waste standards. Many companies resort to this alternative, whereas getting the certification implies complying with the legislation, gaining benefits and promoting an integrated solid waste management system aiming to maintain balance of social, environmental, health, institutional, technical, financial and legal issues in order to provide sustainability to the system (Van de Klundert and Anschütz [6]). As an example, the Rock in Rio event in Brazil decided to adopt the same environmental label, the "100R", as previously acquired on the editions held in Lisbon and in Madrid.

Regardless of the country, solid waste must have a correct destination, implying on a series of laws and regulations to control this activity. The Brazilian standard $\# 12305 / 2010$, that established the National Policy of Solid Waste in Brazil, sought to bring together the best practices around the world. Thus, it is possible to identify some differences between the presented laws (Brazilian Federal Law [7]).

The importance of the environmental issue has increased in business and in daily life, as observed by the great proliferation of products and services that claim to be environmentally friendly, or meet some specific certification requirements.

Despite the great proliferation of certifications and the importance it has taken on environmental marketing companies, events certification was still a relatively unexplored niche by 2012, when only the 100R label was employed. On June 2012, the standard ISO20121 began to be applied, establishing Sustainability Management Systems for Events, created by major organizers of world events, such as members of the sustainability team of the organizing committee of the Olympic games in London (ISO20121 [8]).

"Sociedade Ponto Verde" (Green Point Society) is the Portuguese version of the pioneering Der Gruner Punkt, non-profit organization designed to give a proper destination to packages in Germany. In addition to providing services such as the German version, the Portuguese unit developed different projects, such as the label 100R (Portugal Law [9]). 
The ultimate goal of $100 \mathrm{R}$ is to distinguish companies/organizations that are concerned by environmental issues and take ambitious steps to contribute to a better world. Despite the fact that these measures may result in some economies (for example, cost of landfilling), the major benefit is the public recognition of organizations.

\section{Objective}

This research aims to evaluate the relevance of environmental certification on the issue of solid waste management, in the specific field of major events, based on the Rock in Rio 2011 case and the label 100R.

From this example, the application of an international environmental award can be evaluated at all stages of the waste management process in the operating stage of large events. From the results it is possible to analyze the promotion of environmental sustainability in the generation of waste and the implementation of this control as a permanent urban policy.

\section{Methodology}

This research presents the music festival Rock in Rio, as a case study, to assess the implementation of environmental certification for large events, in order to promote environmental sustainability through waste management and legal compliance with applicable law.

By the description of the case study, the management model is evaluated, analyzing the relevance for the compliance of some standards at a major event and associate those with positive effects such as: valuation of waste for recycling, social inclusion, reduction of costs and environmental marketing.

\section{Case study: the Rock in Rio event}

Rock in Rio (RiR) is a music event that began in Rio de Janeiro in 1985, and had other issues in the city in 1991, 2001 and 2011. During the last interval, the event occurred in two European cities, Lisbon and Madrid, where the issue of sustainability and recycling of solid waste was addressed.

With the return to Brazil, the event, held on a space named Rock City, was willing to follow environmental and social precepts that have adopted in Europe. Among them, stands out the environmental label 100R.

At first, four companies were linked to waste management within the RiR 2011 event space: Municipal Urban Cleaning Company, two (2) private cleaning companies and the Cooperative of separators

In terms of equipment for waste collection, the organization of RiR 2011 bought 520 (five hundred twenty) containers of 240 liters of orange color, which after the event were donated to the Municipal Cleaning Company, to use in the collection of waste of pacified communities of the city of Rio de Janeiro. 
In addition to the 520 (five hundred and twenty) containers, four (4) metal boxes of $5 \mathrm{~m}^{3}$ of volume were placed for the collection of waste. The Municipal Cleaning Company provided two (2) more boxes of $5 \mathrm{~m}^{3}$ and a compactor box of $10 \mathrm{~m}^{3}$. Despite the availability of the compactor box, it could not be used due to lack of a skilled operator.

\subsection{Waste on the Rock City}

To facilitate separation, four (4) categories of waste were defined for the event (1 - Organic, 2 - Non-recyclable waste, 3 - Recyclable waste and 4 - Waste from sweeping) and the process of disposition of each of them was defined, allowing them to be easily identified and consequently routed to their proper temporary destination.

A portion of the recycled waste was separated by the cooperative before leaving the site. All of the waste, both already separated and still mixed, went to weigh in a waste industry and then, when appropriate, followed to its destination to be recycle.

According to the Municipal Cleaning Company, the average waste production in the first weekend of the event was 50 tons per day, were 10 to 12 tons were organic waste, resulting in the daily average of 38-40 tons of waste sent for sorting (RiR Report $[10,11]$ ). According to the recycling cooperative, the amount of recyclable waste removed during the event was approximately 69.0 tons, as described in Table 1 (RiR Report $[10,11])$.

Table 1: Recyclable waste.

\begin{tabular}{|c|c|c|c|c|c|}
\hline \multirow{2}{*}{ Date (2011) } & \multicolumn{5}{|c|}{ Weight (kg) } \\
\cline { 2 - 6 } & Box card & Plastic & Paper & $\begin{array}{c}\text { Aluminium } \\
\text { cans }\end{array}$ & Total/day \\
\hline Sept 23 & 4,500 & 1,500 & 1,700 & 640 & 8,340 \\
\hline Sept 24 & 4,000 & 1,200 & 2,000 & 950 & 8,150 \\
\hline Sept 25 & 4,700 & 1,500 & 1,700 & 1,000 & 8,900 \\
\hline Sept 29 & 6,000 & 2,000 & 2,100 & 950 & 11,050 \\
\hline Sept 30 & 6,400 & 2,300 & 1,900 & 940 & 11,540 \\
\hline Oct 01 & 6,500 & 1,900 & 1,200 & 1,000 & 10,600 \\
\hline Oct 02 & 6,800 & 1,900 & 1,500 & 840 & 11,040 \\
\hline Sub-Total & 38,900 & 12,300 & 12,100 & 6,320 & \\
\hline Total/event & & & & & 69,620 \\
\hline
\end{tabular}

All material collected was separated and packaged before being marketed. Organic waste were sent directly to the composting industry, where it goes through several steps before being transformed into an organic compound that can be used as fertilizer for crops. For Rock in Rio waste, the compound was sent to use in a 
reforestation project of forestry units in the city of Rio de Janeiro. Of all organic waste that was sent to the composting plant, it was possible to use $85 \%$ for organic fertilizer production (Table 2) (RiR Report [10,11]).

Table 2: Composting waste.

\begin{tabular}{|c|c|c|c|c|}
\hline \multirow{2}{*}{ Date (2011) } & \multicolumn{4}{|c|}{ Weight (kg) } \\
\cline { 2 - 5 } & $\begin{array}{c}\text { Organic } \\
\text { compound }\end{array}$ & Evaporated & Landfill & Total \\
\hline Sept 23 & 6,300 & 5,600 & 2,100 & 14,000 \\
\hline Sept 24 & 4,500 & 4,000 & 1,500 & 10,000 \\
\hline Sept 25 & 5,000 & 4,400 & 1,700 & 11,100 \\
\hline Sept 29 & 3,600 & 3,200 & 1,200 & 8,000 \\
\hline Sept 30 & 5,400 & 4,800 & 1,800 & 12,000 \\
\hline Oct 01 & 3,200 & 2,800 & 1,100 & 7,100 \\
\hline Oct 02 & 5,400 & 4,800 & 1,800 & 12,000 \\
\hline Oct 03 & 1,900 & 1,700 & 600 & 4,200 \\
\hline Total & 35,300 & 31,300 & 11,800 & 78,400 \\
\hline Percentage used & & & & $85 \%$ \\
\hline
\end{tabular}

All waste considered potentially recyclable was sent to a waste industry, where it was sorted out by the recycling cooperative. The deadline was October 18 to access and triage these residues. The daily total of this waste can be observed in 0 (RiR Report $[10,11])$.

Table 3: Waste sent for triage in the waste industry.

\begin{tabular}{|c|c|c|c|}
\hline Date (2011) & Weight (kg) & Date (2011) & Weight (kg) \\
\hline Sept 23 & 12,000 & Sept 29 & 20,000 \\
\hline Sept 24 & 30,000 & Sept 30 & 22,000 \\
\hline Sept 25 & 19,000 & Oct 01 & 24,000 \\
\hline Sept 26 & 1,300 & Oct 02 & 29,000 \\
\hline Sept 27 & 1,000 & Oct 03 & 9,100 \\
\hline Sept 28 & 2,100 & Total & $\mathbf{1 6 9 , 5 0 0}$ \\
\hline
\end{tabular}

Only on the first weekend of the event, the waste industry was filled with 60 tons of waste suitable for recycling. The last day of the event was October 02. From Oct 05 the cooperative began to withdraw waste from the industry to route and separation. Only four (4) withdrawn were made: on days $05,06,10$ and 14 of 
October. According to the organization the waste was extremely contaminated which does not justify the separation, because it would endanger the health of their workers. Thus, only $14,600 \mathrm{~kg}$ of residues were removed from storage, and only $10,220 \mathrm{~kg}$ were recycled (the difference was discarded as waste). The totals are presented in Table 4 (RiR Report $[10,11])$.

Table 4: Recyclable residues from the waste industry.

\begin{tabular}{|c|c|c|}
\hline Date (2011) & Removed (kg) & Discarded (kg) \\
\hline Oct 05 & 3,200 & 960 \\
\hline Oct 06 & 3,900 & 1,170 \\
\hline Oct 10 & 3,600 & 1,080 \\
\hline Oct 14 & 3,900 & 1,170 \\
\hline Sub-Totals & 14,600 & 4,380 \\
\hline Total weight & 10,220 & \\
\hline
\end{tabular}

In addition to the recyclable and non-recyclable waste, with the help of a partnership signed with a cooking oil recycling cooperative, Rock in Rio was able to devote $100 \%$ of the oil produced at the event. This oil was used in the project "Recycled Oil, Fisherman benefited" on the city of Arraial do Cabo. The collected oil is processed into biodiesel and used to benefit 750 (seven hundred and fifty) fishermen (RiR Report [10,11]). The amount of collected oil was not very big, as only four (4) establishments used the product. For these establishments, the cooperative provided fifty (50) gallons buckets, which were collected according as they were used (RiR Report $[10,11])$. The amount of oil collected during the event is shown in Table 5 (RiR Report, $2011[10,11]$ ). Considering the cooking oil density of approximately $0.918 \mathrm{~g} / \mathrm{cm}^{3}$, the amount of oil recycled at Rock in Rio was about $1110.8 \mathrm{~kg}(\operatorname{RiR}$ Report $[10,11])$.

Table 5: Total of oil residues from the event.

\begin{tabular}{|l|c|}
\hline \multicolumn{1}{|c|}{ Establishment } & Volume (l) \\
\hline Fried pastry & 50 \\
\hline Arabic food & 420 \\
\hline French fries & 560 \\
\hline Barbecue & 180 \\
\hline \multicolumn{2}{|c|}{ Total } \\
\hline
\end{tabular}

According to the data collected of waste produced during the event, Figure 1 shows the quantity of waste at this stage and the percentage of each type to the total (RiR Report $[10,11])$. 


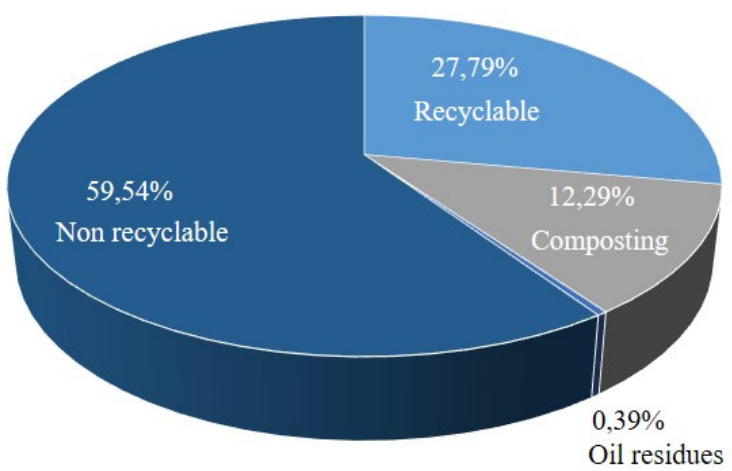

Figure 1: Total residues produced on the event.

\section{Final considerations}

The evolution of the Brazilian legislation and the current situation of solid waste management in the country was detailed in order to contextualize the situation at the time of the event (Rock in Rio 2011), and how it is included in the national context.

This study aimed to discuss and evaluate the Rock in Rio festival in various aspect, such as environmental certification for solid waste, flow of collection and disposal of waste, companies and partnerships developed to implement the project, difficulties faced and reuse and recycling of materials. Despite the adverse situations presented, Rock in Rio Brazil 2011 had a satisfactory result comparing to the previous edition in Portugal.

Rock in Rio was the first event in Brazil to try the environmental certification 100R. This leads to major changes in the organization of events in the country and certainly have a very positive impact on the environmental issue.

Although, as expected, some difficulties were encountered. Dependence on a consumer market for recyclable waste, the lack of contamination control that could guarantee the complete sorting of waste and the lack of previous agreements with buyers for the reused materials.

For future editions, it is important to ensure a way to engage the establishments' participation on separating the waste as it is created. This could be guaranteed through contractual determinations that establish some penalty if the guidelines are not followed. The public encouragement to participate is also essential, so publicity and awareness are essential, both before as well as during the event.

Adopting an environmental certification was important for the organization of the event in committing to properly allocate the waste. It is important to notice that the label 100R does not have targets and indicators to assess whether the event efforts were enough, making it just a commitment of the event. Thus, even if the event achieves a negative result, it can encounter this certification. To obtain 
the label 100R, some actions directed to the correct management, the use of human resources as collectors and the ability to send the waste for recycling have to be met, besides paying the membership fee. Such deficiency on indicators would also be observed if the event decided commit to the ISO20121 Certification.

Despite the difficulties, the initiative and originality make the Rock in Rio event an innovator when it comes to environmental issues in Brazil, and demonstrates a real concern with minimizing the impact caused.

\section{References}

[1] Minghua Z, Xiumin F, Rovetta A, Qichang H, Vicentini F, Bingkai L, Giusti A, Yi L. Municipal solid waste management in Pudong New Area, China. Waste Manage 29: 1227-1233, 2009.

[2] Associação Brasileira De Empresas De Limpeza Pública E Resíduos Especiais (ABRELPE). Panorama dos Resíduos Sólidos no Brasil. São Paulo, 2009.

[3] Srivastava V, Ismail SA, Singh P, Singh RP. Urban solid waste management in the developing world with emphasis on India: challenges and opportunities. Rev Environ Sci Biotechnol 14: 317-337, DOI 10.1007/s11157-014-9352-4, 2015.

[4] Eigenheer, E. A história do lixo: A limpeza urbana através dos tempos, Rio de Janeiro: Editora Campus, 2009.

[5] Guerrero LA, Maas G, Hogland W. Solid waste management challenges for cities in developing countries. Waste Manage 33(1): 220-232, 2013.

[6] Van de Klundert A, Anschütz J. Integrated sustainable waste management - the concept; tools for decision-makers - experiences from the urban waste expertise programme (1995-2001). WASTE, Gauda, Netherlands, 2001.

[7] Brazilian Federal Law \#12.305/2010 - Institui a Política Nacional de Resíduos Sólidos; altera a lei $n^{\circ}$ 9.605, de 12 de fevereiro de 1998; e dá outras providências. Distrito Federal, 2010.

[8] ISO20121, http://www.iso20121.org/ Accessed on January 31, 2013.

[9] Despacho $n^{\circ}$ 454/2006 (2a série): Plano de Intervenção para Resíduos Sólidos e Equiparados. Ministério do Ambiente, do Ordenamento do Território e do Desenvolvimento Regional. Portugal, January, 2006.

[10] Sociedade Ponto Verde. Relatório 100R - RiR 2011. Report elaborated by Sociedade Ponto Verde and the event organization, October, 2011.

[11] Freire, L. M. - Gerenciamento de Resíduos Sólidos em Grandes Eventos e a Relevância de Selos Ambientais. Master dissertation, PEU/UFRJ, 2012. 